\begin{tabular}{cr} 
Jurnal Mitra Manajemen (JMM Online) & $\begin{array}{r}\text { JMM Online } \\
\text { Vol. 3, No. 1, 147-162. } \\
\text { O 2019 Kresna BIP. } \\
\text { URL : http://e-jurnalmitramanajemen.com }\end{array}$ \\
e-ISSN 2614-0365 \\
\hline
\end{tabular}

\title{
FAKTOR-FAKTOR YANG MEMPENGARUHI BRAND EXPERIENCE TEHADAP BRAND LOYALTY PADA IPHONE INDONESIA
}

\author{
Nurlatifah 1), Indira Rachmawati ${ }^{2)}$ \\ Universitas Telkom
}

INFORMASI ARTIKEL

Dikirim : 18 Januari 2019

Revisi pertama : 17 Januari 2019

Diterima : 19 Januari 2019

Tersedia online : 31 Januari 2019

Kata Kunci : Brand Experience, Brand Love, Brand Trust, Brand Identification, Brand Loyalty

Email : nurlatifahmbti@gmail.com ${ }^{1)}$, indirarachmawati@telkomuniversity.ac.id ${ }^{2)}$
ABSTRAK

Alat komunikasi canggih atau yang terkenal dengan smartphone, saat ini sudah menjadi kebutuhan bagi sebagian besar orang. Dengan banyaknya perusahaan smartphone yang ada di Indonesia menyebabkan konsumen lebih sadarakan merek yang ada dan mengenalinya sesuai dengan kebutuhan. Salah satu smartphone flagship yang dikenal konsumen adalah iPhone.

Penelitian ini menggunakan SEM-PLS untuk mengetahui faktor-faktor yang mempengaruhi hubungan antara brand experience (sensory experience, intellectual experience, behavioral experience) terhadap brand loyalty (behavioral loyalty, attitudinal loyalty).

Hasil penelitian menyatakan bahwa seluruh dimensi brand experience berpengaruh positif signifikan terhadap brand love dan brand trust. Brand love dan brand trust berpengaruh positifsignifikan terhadap seluruh dimensi brand loyalty. Brand love memediasi secara signifikan hubungan antara seluruh dimensi brand experience dengan seluruh dimensi brand loyalty kecuali dimensi brand experience (intellectual experience) dengan brand loyalty (attitudinal loyalty). Brand identification tidak memoderasi secara positif signifikan hubungan antara seluruh dimensi brand experience dengan brand love dan brand trust. Brand identification tidak memoderasi secara positif signifikan hubungan antara brand love dan seluruh dimensi brand loyalty. Brand identification memoderasi secara positif signifikan hubungan antara brand trust dan behavioral loyalty. Brand identification tidak memoderasi secara positif signifikan hubungan antara brand trust dan attitudinal loyalty. 


\section{PENDAHULUAN}

\section{Latar Belakang}

Alat komunikasi canggih atau yang terkenal dengan smartphone, saat ini smartphone sudah menjadi kebutuhan bagi sebagian besar orang. Kemajuan teknologi mempengaruhi model berkomunikasi untuk melakukan kegiatan hidup sehari-hari.

Proyeksi penduduk Indonesia (2010-2035) menunjukan setiap tahunnya mengalami peningkatan. Proyeksi dibuat dengan metode komponen berdasarkan asumsi tentang kecenderungan kelahiran, kematian, serta perpindahan penduduk antar provinsi yang paling mungkin terjadi selama periode 25 tahun yang akan datang (Badan Pusat Statistik, 2013:3).

Pada tahun 2015 Lembaga riset digital marketing eMarketer memperkirakan pengguna smartphone di Indonesia (2016-2019) setiap tahunnya mengalami peningkatan (eMarketer, 2015 dalam databoks.katadata.co.id, 2016).

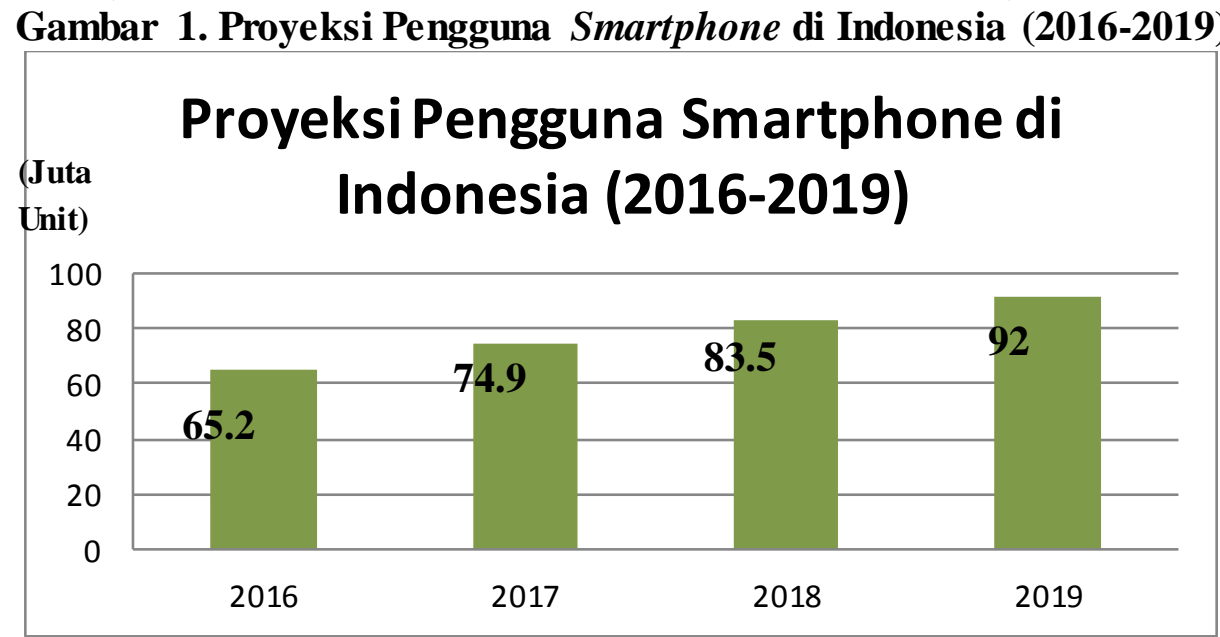

Sumber : eMarketer (2015) dalam databoks.katadata.co.id(2016)

Namun pada tahun 2018 International Data Corporation (IDC) Quarterly Mobile Phone Tracker, menyatakan bahwa pengiriman smartphone di Indonesia mencapai 9.4 juta unit di 2Q18. Pengiriman smartphone di Indonesia mengalami peningkatan $22 \%$ dari kuartal ke kuartal (QoQ) dan peningkatan $18 \%$ dibandingkan periode yang sama tahun sebelumnya. Angka ini menjadi pengiriman tertinggi yang pernah tercatat di Indonesia (idc.com, 2018).

Dari pernyataan International Data Corporation (IDC) di tahun 2018 dapat disimpulkan bahwa, jika pengiriman semakin meningkat maka semakin banyak pengguna yang membeli smartphone.

Perkiraan dari eMarketer di tahun 2015 tentang jumlah proyeksi pengguna smartphone di Indonesia (2016-2019) pada nyatanya melebihi angka proyeksi, dimana angka proyeksi dari tahun 2017 sampai dengan 2018 hanya akan mengalami kenaikan sebesar 8.6 juta unit sedangkan yang sekarang terjadi di tahun 2018 pengiriman smartphone di Indonesia mencapai 9.4 juta unit di 2Q18.

Menurut Global Web Index, kebanyakan negara yang masyarakatnya tertarik untuk membeli iPhone adalah negara-negara berkembang. Indonesia berada di posisi teratas dalam daftar negara yang masyarakatnya menunjukkan ketertarikan pada iPhone 
dengan $41 \%$ pengguna internetnya mengaku berencana membeli iPhone (Amalia, 2016).

Sepanjang kuartal pertama 2017 Apple mengalami penurunan pendapatan yang cukup signifikan dari merosotnya jumlah penjualan iPhone. Penjualan iPhone hanya 50,8 juta unit, melemah dari sebelumnya yang mencapai 51,2 juta unit. Angka ini jauh dari prediksi analis yang memperkirakan penjualan iPhone bisa mencapai 52,2 juta unit pada kuartal pertama yang berakhir 1 April 2017 (Anggraini, 2017).

Pada bulan April 2018 saham Apple secara kumulatif turun 7,1\% dalam tiga hari perdagangan dan membuat kapitalisasi pasarnya turun sampai US\$63,9 miliar (sekitar Rp 891,4 triliun) selama periode tersebut (Sebayang, 2018).

Dari tahun 2016, 2017 dan 2018 smartphone iPhone belum mendapat TOP Brand di Indonesia. Di tahun 2016 TBI iPhone sebesar 5.8\% dan di tahun 2017 turun menjadi 5.1\% lalu di tahun 2018 iPhone tidak masuk dalam kategori IT smartphone.

Alasan pemilihan smartphone diantara jenis gadget lainnya yaitu karena pengguna smartphone Indonesia bertumbuh dengan pesat. Lembaga riset digital marketing Emarketer memperkirakan pada 2018 jumlah pengguna aktif smartphone di Indonesia lebih dari 100 juta orang. Indonesia akan menjadi negara dengan pengguna aktif smartphone terbesar keempat di dunia setelah Cina, India, dan Amerika (Rahmayani, 2016).

Berdasarkan uraian diatas, peneliti tertarik melakukan penelitian untuk mengetahui faktor-faktor yang mempengaruhi brand experience terhadap brand loyalty dalam menggunakan produk iPhone. Brand experience memiliki pengaruh besar terhadap kepuasan pelanggan, karena pelanggan tidak hanya mengharapkan keunggulan fungsi dari produk yang dibeli, namun juga pengalaman yang didapatkan ketika membeli atau mengkonsumsi produk tersebut (Nyohardi, 2016:163).

\section{Rumusan Masalah}

Dengan jumlah proyeksi pertumbuhan penduduk Indonesia (2010-2035) yang setiap tahunnya selalu meningkat dan Indonesia berada sebagai posisi pertama dari TOP 15 Market (iPhone Purchase Concideration) dengan $41 \%$ pengguna internetnya mengaku berencana membeli iPhone namun tetap saja sepanjang kuartal pertama 2017 Apple mengalami penurunan pendapatan yang cukup signifikan dari merosotnya jumlah penjualan iPhone.

Selain itu, presentase TBI iPhone dalam TOP Brand Award di kategori IT smartphone yang diformulasikan berdasarkan tiga variabel yaitu mind share, market share dan commitment share juga dari tahun 2016 hingga 2017 mengalami penurunan, hingga akhirnya tahun 2018 iPhone tidak termasuk dalam kategori IT smartphone TOP Brand Award 2018.

Dengan pertumbuhan penduduk Indonesia yang selalu meningkat iPhone seharusnya dapat memperluas pangsa pasar dan meningkatkan angka penjualan setiap tahunnya. Hali ini menjadi tantangan bagi produsen smartphone iPhone untuk menciptakan dan mempertahankan loyalitas konsumen pada merek perusahaan. Salah satu cara yang dapat dilakukan yaitu menciptakan produk yang berkualitas tinggi dan memberi identitas produk tersebut dengan suatu nama (brand). Hal ini menunjukkan bahwa brand dapat memberikan jaminan kepada konsumen khususnya pada kualitas 
dan manfaat yang terdapat pada suatu merek produk. Kualitas yang baik dari suatu merek produk akan berdampak terhadap tinggi rendahnya loyalitas konsumen terhadap merek.

Dengan mengetahui brand experience yang dimediasi oleh brand love dan brand trust serta di moderasi oleh brand identification apakah akan mempengaruhi brand loyalty untuk pengguna iPhone di Indonesia untuk membeli iPhone keluaran terbaru yaitu iPhone XS, iPhone XS Max, dan iPhone XR atau membeli iPhone seri sebelumnya, dan juga dapat memudahkan perusahaan Apple untuk dapat mengambil langkah-langkah yang akan dilakukan guna meningkatkan penjualan mereka. Dan bagaimana perusahaan juga mampu menentukan strategi yang harus dilakukan agar setiap kosumen baik yang melihat dari sisi kualitas dan dari sisi harga dapat memutuskan untuk tetap loyal terhadap produk iPhone, sehingga mereka melakukan pembelian ulang. Keberadaan konsumen yang loyal pada brand iPhone sangat diperlukan agar perusahaan dapat bertahan hidup.

\section{Tujuan Penelitian}

Berdasarkan rumusan masalah diatas, maka tujuan dalam penelitian ini adalah sebagai berikut.

1. Untuk mengetahui apakah Brand Experience (Sensory Experience, Intellectual Experience, Behavioral Experience) berpengaruh secara positif dan signifikan terhadap brand love.

2. Untuk mengetahui apakah Brand Experience (Sensory Experience, Intellectual Experience, Behavioral Experience) berpengaruh secara positif dan signifikan terhadap Brand Trust.

3. Untuk mengetahui apakah Brand Love berpengaruh secara positif dan signifikan terhadap Brand Loyalty (Behavioral Loyalty, Attitudinal Loyalty).

4. Untuk mengetahui apakah Brand Trust berpengaruh secara positif dan signifikan terhadap Brand Loyalty (Behavioral Loyalty, Attitudinal Loyalty).

5. Untuk mengetahui apakah Brand Love memediasi secara signifikan pada hubungan antara Brand Experience (Sensory Experience, Intellectual Experience, Behavioral Experience) dan Brand Loyalty (Behavioral Loyalty, Attitudinal Loyalty).

6. Untuk mengetahui apakah Brand Trust memediasi secara signifikan pada hubungan antara Brand Experience (Sensory Experience, Intellectual Experience, Behavioral Experience) dan Brand Loyalty (Behavioral Loyalty, Attitudinal Loyalty).

7. Untuk mengetahui apakah Brand Identification memoderasi secara positif dan signifikan pada hubungan antara Brand Experience (Sensory Experience, Intellectual Experience, Behavioral Experience) dan Brand Love.

8. Untuk mengetahui apakah Brand Identification memoderasi secara positif dan signifikan hubungan antara Brand Experience (Sensory Experience, Intellectual Experience, Behavioral Experience) dan Brand Trust.

9. Untuk mengetahui apakah Brand Identification memoderasi secara positif dan signifikan hubungan antara Brand Love dan Brand Loyalty (Behavioral Loyalty, Attitudinal Loyalty). 
10. Untuk mengetahui apakah Brand Identification memoderasi secara positif dan signifikan hubungan antara Brand Trust dan Brand Loyalty (Behavioral Loyalty, Attitudinal Loyalty).

11. Untuk mengetahui tingkat performance-importance Brand Loyalty (Behavioral Loyalty dan Attitudinal Loyalty).

\section{KAJIAN PUSTAKA}

\section{Brand Experience}

Menurut Brakus et al. (2009) dalam Sidabutar dan Dharmayanti (2015:3), terdapat 4 dimensi brand experience:

1. Sensori : pendekatan dengan menggunakan rasa pelanggan untuk mengukur pengalaman pelanggan.

2. Afektif : pendekatan perasaan dan emosional pelanggan untuk mengukur pengalaman pelanggan.

3. Intelektual: menggunakan kemampuan merek untuk terlibat dengan pelanggan.

4. Perilaku : menggunakan pengalaman tubuh, gaya hidup dan interaksi dengan merek untuk mengukur pengalaman pelanggan

\section{Brand Loyalty}

Dalam buku Schiffman et al. (2012:223), marketers menyatakan bahwa brand loyalty terdiri dari sikap (attitudes) dan (actual behaviours) terhadap sebuah merek dan keduanya harus diukur. Pengukuran sikap (attitudinal) yaitu berhubungan dengan perasaan keseluruhan konsumen seperti penilaian konsumen tentang produk dan adanya minat beli konsumen. Pengukuran perilaku (behavioral) didasarkan pada respons yang dapat diamati terhadap rangsangan promosi - perilaku pembelian berulang bukan sikap terhadap produk atau merek.

\section{Brand Love}

Betra et al. (2012) dalam bambang et al. (2017:164), menyimpulkan bahwa konsumen, menampilkan lebih banyak loyalitas kepada merek yang dicintai. Khayeri et al. (2013) dalam bambang et al. (2017:164), menunjukkan bahwa konsumen, yang ditemukan memiliki keterikatan emosional, menunjukkan tingkat loyalitas yang lebih tinggi, menyebarkan lebih banyak kata dari mulut ke mulut tentang merek dan bersedia membayar harga yang lebih tinggi untuk merek.

\section{Brand Trust}

Menurut Kustini et al. (2011) dalam Sari dan Widowati (2014:66) , brand trust dapat diukur melalui dimensi viabilitas (dimension of viability) dan dimensi intensionalitas (dimension of intentionality).

1. Dimension of Viability mewakili sebuah persepsi bahwa suatu merek dapat memenuhi dan memuaskan kebutuhan dan nilai konsumen. Dimensi ini dapat diukur melalui indikator kepuasan dan nilai (value).

2. Dimension of Intentionality mencerminkan perasaan aman dari seorang individu terhadap suatu merek. Dimensi ini dapat diukur melalui indikator security dan trust. 


\section{Brand Identification}

Ghodeswar (2008) dalam Sudrajat (2015:19), menyatakan bahwa brand identification adalah seperangkat unik asosiasi merek yang memenuhi jaringan atau mempertahankan strategi pemasaran merek. Asosiasi ini mewakili apa yang merek berdiri dan menyiratkan pelanggan yang menjanjikan. Agar efektif, brand identification diperlukan untuk memahami pelanggan, membedakan merek dari pesaing, dan mewakili apa yang perusahaan bisa dan akan lakukan dari waktu ke waktu (Underwood, 2003).

\section{Kerangka Pemikiran}

Pada penelitian ini penulis melakukan replikasi pada kerangka pemikiran yang dibuat oleh Huang (2017). Kerangka pemikiran dapat dilihat pada Gambar 2.

\section{Gambar 2. Kerangka Penelitian}

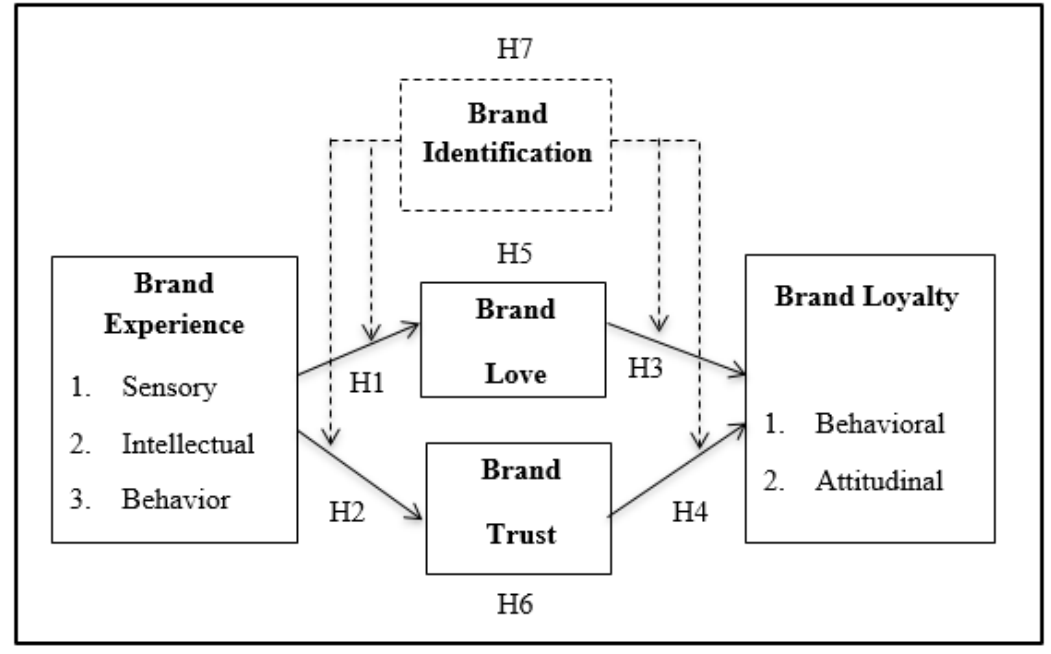

Sumber : Huang (2017: 918)

Dengan demikian penelitian ini memiliki hipotesis sebagai berikut:

H1a. Sensory experience memiliki efek positif pada brand love.

H1b. Intellectual Experience memiliki efek positif pada brand love.

H1c. Behavioal Experience memiliki efek positif pada brand love

H2a. Sensory experience memiliki efek positif pada brand trust.

$\mathrm{H} 2 \mathrm{~b}$. Intellectual Experience memiliki efek positif pada brand trust.

H2C. Behavioal Experience memiliki efek positif pada brand trust.

H3a. Brand love memiliki efek positif pada behavioral loyalty.

H3b. Brand Love memiliki efek positif pada attitudinal loyalty.

H4a. Brand trust memiliki efek positif pada behavioral loyalty.

H4b. Brand Trust memiliki efek positif pada attitudinal loyalty.

H5a. Brand love memiliki efek mediasi pada hubungan antara sensory experience dan behavioral loyalty.

H5b. Brand love memiliki efek mediasi pada hubungan antara Intellectual experience dan behavioral loyalty.

H5c. Brand love memiliki efek mediasi pada hubungan antara Behavioral experience dan behavioral loyalty. 
H5d. Brand love memiliki efek mediasi pada hubungan antara sensory experience dan attitudinal loyalty.

H5e. Brand love memiliki efek mediasi pada hubungan antara Intellectual experience dan atitudinal loyalty.

H5f. Brand love memiliki efek mediasi pada hubungan antara Behavioral experience dan attitudinal loyalty.

H6a. Brand Trust memiliki efek mediasi pada hubungan antara sensory experience dan behavioral loyalty.

H6b. Brand Trust memiliki efek mediasi pada hubungan antara Intellectual experience dan behavioral loyalty.

H6c. Brand Trust memiliki efek mediasi pada hubungan antara Behavioral experience dan behavioral loyalty.

H6d. Brand Trust memiliki efek mediasi pada hubungan antara sensory experience dan attitudinal loyalty.

H6e. Brand Trust memiliki efek mediasi pada hubungan antara Intellectual experience dan atitudinal loyalty.

H6f. Brand Trust memiliki efek mediasi pada hubungan antara Behavioral experience dan attitudinal loyalty.

H7a. Brand identification memiliki efek moderasi pada hubungan antara sensory experience dan brand love.

H7b. Brand identification memiliki efek moderasi pada hubungan antara intellectual experience dan brand love.

H7c. Brand identification memiliki efek moderasi pada hubungan antara behavior experience dan brand love.

H8a. Brand identification memiliki efek moderasi pada hubungan antara sensory experience dan brand trust.

H8b. Brand identification memiliki efek moderasi pada hubungan antara intellectual experience dan brand trust.

H8c. Brand identification memiliki efek moderasi pada hubungan antara behavior experience dan brand trust.

H9a. Brand identification memiliki efek moderasi pada hubungan antara brand love dan behavioral loyalty.

H9b. Brand identification memiliki efek moderasi pada hubungan antara brand love dan attitudinal loyalty.

H10a. Brand identification memiliki efek moderasi pada hubungan antara brand trust dan behavioral loyalty.

H10b. Brand identification memiliki efek moderasi pada hubungan antara brand trust dan attitudinal loyalty.

\section{METODE PENELITIAN}

Metode Penelitian yang digunakan dalam penelitian ini adalah penelitian kuantitatif. Metode penelitian kuantitatif adalah metode yang mencoba melakukan pengukuran yang akurat terhadap perilaku, pengetahuan, opini atau sikap (Cooper dan Schinder, 2011 dalam Indrawati, 2015:184). Teknik pengumpulan data yang digunakan oleh peneliti adalah survey melalui penyebaran kuesioner. 
Teknik sampling yang digunakan dalam penelitian ini adalah non probability sampling dengan purposive sampling dengan jenis quota sampling berdasarkan jumlah penduduk (WIB, WITA, WIT) dengan jumlah sebanyak 400 responden pengguna iPhone di indonesia. Pengambilan sampel dilakukan dengan menyebarkan kuesioner secara online via Google Form.

Teknik pengolahan data yang digunakan dalam penelitian ini adalah PLS-SEM, Partial Least Squares (PLS) dengan menggunakan SmartPLS 3.2.8.

\section{HASIL PENELITIAN DAN PEMBAHASAN KARAKTERISTIK RESPONDEN}

Berdasarkan hasil penyebaran kuesioner terhadap 400 responden, didapat karakteristik responden sebagai berikut :

1. Mayoritas responden berjenis kelamin perempuan sebanyak 237 responden (59\%), mayoritas berusia 17-25 tahun sebanyak 311 responden (78\%).

2. Domisili berdasarkan tempat tinggal wilayah indonesia bagian barat sebanyak 324 responden (81\%), bagian tengah sebanyak 64 responden $(16 \%)$ dan bagian timur sebanyak 12 responden (3\%).

3. Mayortitas berdasarkan lama menghabiskan waktu menggunakan smartphone dalam satu minggu sebanyak 217 responden (54\%) adalah 9-24 Jam/Minggu.

4. Berdasarkan pekerjaan pada penelitian ini didominasi pelajar atau mahasiswa. Di mana pelajar atau mahasiswa berjumlah 230 atau sebesar $57 \%$ selanjutnya pegawai swasta berjumlah 50 atau sebesar $12 \%$, entrepreneur (wirausahawan) berjumlah 40 atau sebesar $10 \%$, PNS berjumlah 18 atau 5\%, pelajar atau mahasiswa yang juga sebagai entrepreneur (wirausahawan) berjumlah 18 atau 5\%, pengusaha berjumlah 14 atau 4\%, lainnya berjumlah 17 atau 4\%, ibu rumah tangga berjumlah 13 atau $3 \%$.

5. Seri iPhone yang digunakan saat ini didominasi oleh iPhone 6/ iPhone 6 Plus/ iPhone 6s / iPhone 6s Plus sebanyak 169 atau sebesar 42\%. Selanjutnya adalah iPhone 7 / iPhone 7 Plus sebanyak 103 atau sebesar 26\%, iPhone 8/ 8 Plus sebanyak 47 atau sebesar 12\%, iPhone 5 / iPhone 5s / iPhone 5c / iPhone SE sebanyak 47 atau sebesar 12\%, iPhone (X, XS, XS Max, XR) sebanyak 30 atau sebesar 7\% dan iPhone (4/4S) sebanyak 4 atau sebesar $1 \%$.

6. Lama responden sudah menggunakan iPhone didominasi 1-2 Tahun sebanyak 180 atau sebesar $45 \%$. Selanjutnya adalah 2-4 sebanyak 147 atau sebesar 37\%, Lebih dari 4 tahun sebanyak 68 atau sebesar 17\% dan kurang dari 1 tahun sebanyak 5 atau sebesar $1 \%$.

7. Cara responden mendapatkan iPhone didominasi dengan cara membeli sendiri dengan uang orang tua / orang lain sebanyak 126 atau sebesar 32\%. Selanjutnya dengan cara dibelikan orang tua/orang lain atas permintaan responden sebanyak 121 atau sebesar $30 \%$. Membeli sendiri dengan uang sendiri sebanyak 115 atau sebesar $29 \%$, Dibelikan orang tua/orang lain atas kemauan orang tua/orang lain sebanyak 20 atau sebesar 5\% dan Hadiah / Warisan sebanyak 18 atau sebesar 4\%. 


\section{MODEL PENGUKURAN (OUTER MODEL)}

\section{a. Validitas Convergent}

Suatu indikator dikatakan mempunyai validitas yang baik jika memiliki nilai loading factor lebih besar dari 0,70. Berdasarkan hasil pengujian AVE seluruh variabel dalam penelitian memiliki nilai Average Variance Extracted (AVE) lebih besar dari 0.5 dan dinyatakan valid. Menurut Ghozali \& Latan (2015:760) bahwa nilai AVE harus lebih besar dari 0.5 .

\section{b. Validitas Discriminant}

Berdasarkan hasil pengujian cross loading, seluruh nilai loading lebih besar dibandingkan dengan nilai cross loadingnya , serta memiliki nilai lebih dari 0.7 dan dinyatakan valid. Menurut Ghozali \& Latan (2015:76) nilai cross loading yang valid adalah lebih besar dari 0.7. Selanjutnya berdasarkan pengujian Fornell-Larcker criterion menunjukkan bahwa nilai akar kuadrat AVE pada setiap variabel lebih tinggi dibandingkan dengan nilai korelasi maka dapat disimpulkan bahwa model valid. Menurut Ghozali \& Latan (2015:97) untuk memenuhi discriminant validity nilai akar kuadrat AVE lebih tinggi daripada nilai korelasi antar konstruk.

\section{c. Reliabilitas}

Berdasarkan hasil pengujian reliabilitas, selutuh variabel dalam penelitian ini memiliki nilai cronbach's alpha dan composite reliability lebih besar dari 0.7 dan dinyatakan reliabel. Menurut Ghozali \& Latan (2015:77) nilai cronbach's alpha dan composite reliability harus lebih besar dari 0.7 .

\section{PENGUJIAN MODEL STRUKTURAL (INNER MODEL)}

\section{R Square}

Tabel 1. R Square Adjusted

\begin{tabular}{|l|l|}
\hline & R Square Adjusted \\
\hline BLV & 0.650 \\
\hline BT & 0.714 \\
\hline BLY & 0.641 \\
\hline ALY & 0.586 \\
\hline
\end{tabular}

Sumber : Hasil Penelitian, diolah (2018)

Menurut Chin (1998) dalam Ghozali dan Latan (2015:81), R Square Adujusted dengan nilai 0.67 menunjukan model kuat, nilai 0.33 menunjukan model moderate dan nilai 0.19 menunjukan model lemah.

Dari hasil Tabel 1 dapat dilihat $R$-Square Adujusted untuk variabel Brand Love (BLV) sebesar 0.650 yang berarti bahwa Sensory Experience (BES), Intellectual Experience (BEI), Behavioral Experience (BEB), Sensory Experience dimoderasi Brand Identification (BI*BES), Intellectual Experience dimoderasi Brand Identification (BI*BEI), dan Behavioral Experience dimoderasi Brand Identification (BI*BEB) memberikan kontribusi pengaruh sebesar 0.650 atau $65.0 \%$ terhadap Brand Love dengan kategori moderate. Sedangkan sisanya sebesar $35.0 \%$ merupakan pengaruh dari faktor lain yang tidak diamati.

R-Square Adujusted untuk variabel Brand Trust (BT) sebesar 0.714 yang berarti bahwa Sensory Experience (BES), Intellectual Experience (BEI), Behavioral 
Experience (BEB), Sensory Experience dimoderasi Brand Identification (BI*BES), Intellectual Experience dimoderasi Brand Identification (BI*BEI), dan Behavioral Experience dimoderasi Brand Identification (BI*BEB) memberikan kontribusi pengaruh sebesar 0.714 atau $71.4 \%$ terhadap Brand Trust (BT) dengan kategori kuat. Sedangkan sisanya sebesar $28.6 \%$ merupakan pengaruh dari faktor lain yang tidak diamati.

$R$-Square Adujusted untuk variabel Behavioral Loyalty (BLY) sebesar 0.641 yang berarti bahwa Brand Love (BLV), Brand Trust (BT), Brand Love dimoderasi Brand Identification $(\mathrm{BI} * \mathrm{BLV})$, dan Brand Trust dimoderasi Brand Identification (BI*BT) memberikan kontribusi pengaruh sebesar 0.641 atau $64.1 \%$ terhadap Behavioral Loyalty (BLY) dengan kategori moderate. Sedangkan sisanya sebesar $35.9 \%$ merupakan pengaruh dari faktor lain yang tidak diamati.

Sedangkan $R$-Square Adujusted untuk variabel Attitudinal Loyalty (ALY) sebesar 0.586 yang berarti bahwa Brand Love (BLV), Brand Trust (BT), Brand Love dimoderasi Brand Identification (BI*BLV), dan Brand Trust dimoderasi Brand Identification (BI*BT) memberikan kontribusi pengaruh sebesar 0.586 atau $58.6 \%$ terhadap Attitudinal Loyalty (ALY) dengan kategori moderate. Sedangkan sisanya sebesar $41.4 \%$ merupakan pengaruh dari faktor lain yang tidak diamati.

\section{Q-square.}

Tabel 2. Q-square

\begin{tabular}{|l|l|l|l|}
\hline & SSO & SSE & $\mathbf{Q}^{2}(=\mathbf{1 - S S E} /$ SSO) \\
\hline ALY & $1,200.000$ & 663.617 & 0.447 \\
\hline BLV & $2,000.000$ & $1,016.055$ & 0.492 \\
\hline BLY & $1,200.000$ & 595.318 & 0.504 \\
\hline BT & $3,200.000$ & $1,743.461$ & 0.455 \\
\hline
\end{tabular}

Sumber : Hasil Penelitian, diolah (2018)

Nilai $Q$-square lebih besar dari 0 (nol) menunjukkan bahwa model mempunyai nilai predictive relevance, sedangkan $Q$-square kurang dari 0 (nol) menunjukkan bahwa model kurang memiliki predictive relevance (Ghozali dan Latan, 2015:81). Tabel 2 menunjukkan bahwa nilai $Q$-square seluruh konstruk lebih besar dari 0 (nol). Sehingga dapat disimpulkan bahwa model penelitian memiliki nilai predictive relevance yang baik.

\section{F Square}

Dalam buku Ghozali dan Latan (2015:81) dijelaskan bahwa F Square digunakan untuk melihat pengaruh prediktor variabel laten pada level struktural. Nilai F Square sebesar 0.02 menunjukan rating kecil, Effect Size 0.15 menunjukan rating menengah dan Effect Size 0.35 menunjukan rating besar.

Tabel 3. F Square

\begin{tabular}{|l|l|l|}
\hline BLV & Effect Size & Rating \\
\hline BES & 0,014 & Kecil \\
\hline BEI & 0,038 & Kecil \\
\hline BEB & 0,127 & Kecil \\
\hline
\end{tabular}


Lanjutan Tabel 3. F Square

\begin{tabular}{|l|l|l|}
\hline BT & Effect Size & Rating \\
\hline BES & 0,028 & Kecil \\
\hline BEI & 0,089 & Kecil \\
\hline BEB & 0,073 & Kecil \\
\hline BLY & Effect Size & Rating \\
\hline BLV & 0,092 & Kecil \\
\hline BT & 0,070 & Kecil \\
\hline ALY & Effect Size & Rating \\
\hline BLV & 0,022 & Kecil \\
\hline BT & 0,058 & Kecil \\
\hline
\end{tabular}

Sumber : Hasil Penelitian, diolah (2018)

Berdasarkan Tabel 3 menunjukkan bahwa seluruh variabel independen yang mempengaruhi dependen termasuk dalam kategori kecil. Hal tersebut memiliki arti bahwa dengan hadirnya variabel independen akan berdampak kecil terhadap perubahan yang terjadi pada variabel dependen.

Hasil pengujian hipotesis menggunakan aplikasi program SmartPLS 3.2.8 dapat dilihat pada Tabel 4.

Tabel 4. Hasil Pengujian Hipotesis

\begin{tabular}{|l|l|l|l|l|l|}
\hline Hipotesis & \multicolumn{1}{|c|}{ Pengaruh } & $\begin{array}{c}\text { Path } \\
\text { Coefficients }\end{array}$ & t-value & $\begin{array}{c}\text { p- } \\
\text { value }\end{array}$ & Keterangan \\
\hline H1a & BES-B LV & 0.093 & 2.241 & 0.013 & Diterima \\
\hline H1b & BEI-BLV & 0.173 & 3.572 & 0.000 & Diterima \\
\hline H1c & BEB-BLV & 0.302 & 6.376 & 0.000 & Diterima \\
\hline H2a & BES-BT & 0.120 & 3.168 & 0.001 & Diterima \\
\hline H2b & BEI-B T & 0.240 & 5.850 & 0.000 & Diterima \\
\hline H2c & BEB-BT & 0.205 & 5.434 & 0.000 & Diterima \\
\hline H3a & BLV-BLY & 0.330 & 5.749 & 0.000 & Diterima \\
\hline H3b & BLV-ALY & 0.173 & 2.822 & 0.002 & Diterima \\
\hline H4a & BT-BLY & 0.305 & 4.799 & 0.000 & Diterima \\
\hline H4b & BT-ALY & 0.298 & 4.445 & 0.000 & Diterima \\
\hline H5a & BES-BLV-BLY & 0.031 & 2.099 & 0.036 & Diterima \\
\hline H5b & BEI-BLV-BLY & 0.057 & 3.043 & 0.002 & Diterima \\
\hline H5c & BEB-B LV -BLY & 0.099 & 4.038 & 0.000 & Diterima \\
\hline H5d & BES-B LV-ALY & 0.016 & 1.746 & 0.081 & Ditolak \\
\hline H5e & BEI-BLV-ALY & 0.030 & 2.194 & 0.028 & Diterima \\
\hline H5f & BEB-B LV -ALY & 0.052 & 2.490 & 0.013 & Diterima \\
\hline H6a & BES-BT-BLY & 0.037 & 2.560 & 0.011 & Diterima \\
\hline H6b & BEI-B T-BLY & 0.073 & 3.800 & 0.000 & Diterima \\
\hline H6c & BEB-B T-BLY & 0.063 & 3.331 & 0.001 & Diterima \\
\hline H6d & BES-B T-ALY & 0.036 & 2.514 & 0.012 & Diterima \\
\hline H6e & BEI-BT-ALY & 0.072 & 3.912 & 0.000 & Diterima \\
\hline H7a & BI*BES-BLV & -0.047 & 1.080 & 0.104 & Ditolak \\
\hline
\end{tabular}




\begin{tabular}{|l|l|l|l|l|l|}
\hline Hipotesis & \multicolumn{1}{|c|}{ Pengaruh } & $\begin{array}{c}\text { Path } \\
\text { Coefficients }\end{array}$ & t-value & $\begin{array}{c}\text { p- } \\
\text { value }\end{array}$ & Keterangan \\
\hline H7b & BI*BEI-BLV & 0.076 & 1.560 & 0.059 & Ditolak \\
\hline H7c & BI*BEB-BLV & -0.185 & 4.054 & 0.000 & Ditolak \\
\hline H8a & BI*BES-BT & -0.069 & 1.994 & 0.023 & Ditolak \\
\hline H8b & BI*BEI-BT & 0.040 & 0.828 & 0.204 & Ditolak \\
\hline H8c & BI*BEB-B T & -0.172 & 3.987 & 0.000 & Ditolak \\
\hline H9a & BI*BLV-BLY & -0.114 & 2.063 & 0.020 & Ditolak \\
\hline H9b & BI*BLV*ALY & -0.004 & 0.070 & 0.472 & Ditolak \\
\hline H10a & BI*BT-B LY & 0.117 & 2.064 & 0.020 & Diterima \\
\hline H10b & BI*BT*ALY & -0.007 & 0.135 & 0.446 & Ditolak \\
\hline
\end{tabular}

Sumber : Hasil Penelitian, diolah (2018)

Dengan tingkat kepercayaan 95\% (alpha 5\%), dengan jumlah responden 400 orang maka diperoleh nilai t-tabel sebagai berikut:

1. One Tiled (digunakan untuk pengaruh langsung dan moderasi) : Jika nilai t-statistik $\geq 1.64$ maka $\mathrm{H} 0$ ditolak dan $\mathrm{H} 1$ diterima Jika nilai t-statistik < 1.64 maka $\mathrm{H} 0$ diterima dan $\mathrm{H} 1$ ditolak

2. Two Tailed (digunakan untuk pengaruh mediasi) :

Jika nilai t-statistik $\geq 1.96$ maka $\mathrm{H} 0$ ditolak dan $\mathrm{H} 1$ diterima $(-1.96 \geq$ t-statistik $>1.96)$

Jika nilai t-statistik < 1.96 maka $\mathrm{H} 0$ diterima dan $\mathrm{H} 1$ ditolak $(-1.96<$ t statistik $<1.96)$

3. Menurut Hair et al., (2017: 188), nilai pengaruh signifikan jika p-value $<0.05$

Berdasarkan Tabel 4 terdapat 32 hipotesis pada penelitian ini yang terbagi menjadi 10 hipotesis untuk pengaruh langsung (H1a-H4b), 12 hipotesis untuk pengaruh mediasi (H5a-H6f) dan 10 hipotesis untuk pengaruh moderasi (H7aH10b). Tabel 4 menunjukan bahwa terdapat 22 hipotesis diterima dan 10 hipotesis ditolak.

\section{IMPORTANCE PERFORMANCE MATRIX ANALYSIS (IPMA)}

Pembahasan IPMA Behavioral Loyalty dan Attitudinal Loyalty :

a. BES 3 dan BES 1 BEB1 dan BEB2 BLV5, BLV6, BLV8 dan BLV 9 BTI1, BTI2, BTF2, BTF3, BTF4, BTF5 BI3 berada pada kuadran I yaitu "Keep Up Good Work" dimana tingkat kepentingan tinggi dan tingkat kinerja tinggi. Maka dari itu kuadran ini mewakili peluang untuk mendapatkan atau mempertahankan level yang lebih tinggi dari konstruk (Latan dan Noonan, 2017:370).

b. BES 2, BEI1 dan BEI2 BEB3 BLV10 BTI3 dan BTI5 berada pada kuadran II yaitu "Concentrate Here" berarti merupakan elemen kunci untuk perbaikan, karena konstruk ini dianggap paling penting oleh responden(Latan dan Noonan, 2017:370).

c. BEI3, BI5 berada pada kuadran IV yaitu "Possible Overkill", dimana tingkat kinerja dari perusahaan tinggi namun responden tidak menganggap konstruk tersebut penting. Oleh karena itu, disarankan untuk memindahkan sumber daya ke tempat lain (Latan dan Noonan, 2017:370). 
d. BI4 berada pada kuadran III yaitu "low priority" dengan kepentingan rendah serta kinerja rendah, maka driver ini tidak perlu mendapat perhatian khusus atau upaya tambahan (Latan dan Noonan, 2017:370).

\section{KESIMPULAN DAN SARAN}

\section{Kesimpulan}

Berdasarkan hasil analisis dan pengujian statistik pada penelitian ini, dapat disimpulkan beberapa hal mengenai faktor-faktor yang mempengaruhi brand experience terhadap brand loyaty pada iPhone Indonesia sebagai berikut:

1. Brand Experience (sensory experience, intellectual experience dan behavioral experience) berpengaruh secara positif signifikan terhadap brand love.

2. Brand Experience (sensory experience, intellectual experience dan behavioral experience) berpengaruh secara positif signifikan terhadap brand trust.

3. Brand love berpengaruh secara positif signifikan terhadap brand loyalty (behavioral loyalty dan attitudinal loyalty).

4. Brand trust berpengaruh secara positif signifikan terhadap brand loyalty (behavioral loyalty dan attitudinal loyalty).

5. Brand love memediasi secara signifikan hubungan antara brand experience (sensory experience, intellectual experience, behavioral experience) dengan behavioral loyalty. Selanjutnya brand love memediasi secara signifikan hubungan antara brand experience (intellectual experience, behavioral experience) dengan brand loyalty (attitudinal loyalty). Namun brand love tidak memediasi secara signifikan hubungan antara brand experience (sensory experience) dengan brand loyalty (attitudinal loyalty).

6. Brand trust memediasi secara signifikan hubungan antara brand experience dengan brand loyalty (behavioral loyalty, attitudinal loyalty).

7. Brand identification tidak memoderasi secara positf signifikan hubungan antara brand experience (sensory experience, intellectual experience, behavioral experience) dengan brand love.

8. Brand identification tidak memoderasi secara positf signifikan hubungan antara brand experience (sensory experience, intellectual experience, behavioral experience) dengan brand trust.

9. Brand identification tidak memoderasi secara positf signifikan hubungan antara brand love dengan brand loyalty (behavioral loyalty, attitudinal loyalty).

10. Brand identification memoderasi secara positf signifikan hubungan antara brand trust dengan brand loyalty (behavioral loyalty). Namun brand identification tidak memoderasi secara positf signifikan hubungan antara brand trust dan attitudinal loyalty.

11. Tingkat importance dan performance pada kuadran I atau "Keep Up the Good Work" meliputi indikator BES 3, BES 1, BEB1, BEB2, BLV5, BLV6, BLV8, BLV 9, BTI1, BTI2, BTF2, BTF3, BTF4, BTF5 BI3. Pada kuadran II yaitu "Concentrate Here" meliputi indikator BES2, BEI1, BEI2, BEB3, BLV10, BTI3, BTI5. Pada kuadran III yaitu "low priority" meliputi indikator BI4. Pada kuadran IV yaitu "Possible Overkill" meliputi indikator BEI3, BI5. 


\section{Saran}

1. Saran Bagi Perusahaan

iPhone Indonesia harus memperbaiki variabel brand experience pengguna, untuk dimensi pertama yaitu sensory experience yang harus diperbaiki adalah menarik dalam sensori (BES2). Selanjutnya untuk dimensi kedua yaitu intellectual experience yang harus diperbaiki adalah pengguna terajak dalam banyak hal berpikir ketika menemui merek ini (BEI1) dan merek ini mengarahkan pengguna berpikir positif (BEI2). Selanjutnya dimensi ketiga yaitu behavioral experience yang harus diperbaiki adalah merek ini berorientasi bukan pada tindakan (BEB3). Brand experience saat ini menjadi salah satu fokus yang sangat diperhatikan olek pihak produsen produk atau jasa untuk meningkatkan kualitas merek mereka. Jika perusahaan mampu memperbaikinya maka akan berdampak pada behavioral loyalty dan attitudinal loyalty.

iPhone indonesia harus memperbaiki variabel brand love dengan meningkatkan kecintaan merek penggunanya, yang harus diperbaiki adalah membuat pengguna sangat terikat dengan merek ini (BLV10). Jika kecintaan merek tercapai, maka akan berdampak baik terhadap kesetiaan perilaku dimana konsumen yang memiliki keterikatan emosional, menunjukan tingkat loyalitas yang lebih tinggi, menyebarkan informasi dari mulut ke mulut dan bersedia membayar harga yang lebih tinggi untuk merek sehingga berdampak pada konsistensi perusahaan dan peningkatan profitabilitas.

iPhone indonesia harus memperbaiki variabel brand trust dengan merek ini dapat lebih diandalkan pengguna untuk memecahkan masalahan (BTI3) dan meningkatkan kompensasi jika terdapat masalah pada smartphone (BTI5), dikarenakan kepercayaan merek menjadi faktor paling penting dalam kesetiaan sikap dan dampak pada perilaku pengguna terhadap merek. Jika kepercayaan merek tercapai, maka akan berdampak baik terhadap kesetiaan sikap dimana pengguna bersedia mempercayai suatu merek dengan segala resikonya karena adanya harapan dibenak pengguna bahwa merek iPhone akan memberikan hasil yang positif sehingga menimbulkan kesetiaan pada iPhone dan juga berdampak pada konsistensi perusahaan dan peningkatan profitabilitas.

2. Saran Bagi Akademis

Model ini hanya mampu mengukur behavioral loyalty sebesar 64.1\%, attitudinal loyalty sebesar 58.6\%. Selanjutnya Brand love pada model ini hanya mampu memberikan mediasi/perantara sebesar sebesar 65\% antara brand experience terhadap brand loyalty, kemudian brand trust pada model ini hanya mampu memberikan mediasi/perantara sebesar sebesar 71.4\%, antara brand experience terhadap brand loyalty. Hal ini menunjukkan bahwa penyesuaian dan pengembangan konstruk diperlukan untuk meningkatkan tingkat keakuratan. Oleh karena itu, saran yang diberikan kepada penelitian selanjutnya yaitu harus memeriksa dimensi spesifik brand love seperti passion driven behavior, self-brand integration, positive emotional connection (Batra et al., 2009).

Selain itu, di masa mendatang berkemungkinan adanya perubahan pada faktor-faktor yang mempengaruhi brand experience sehingga berdampak pada iPhone Indonesia. Untuk itu, di masa mendatang penelitian lainnya dapat 
menggabungkan variabel lain ke dalam model penelitian sesuai dengan fenomena dan permasalahan yang terjadi.

\section{DAFTAR PUSTAKA}

Abdillah, Willy dan Hartono, Jogiyanto. (2015). Partial Least Square (PLS). Yogyakarta : ANDI.

Amalia, I. A. (2016). Peminat iPhone Paling Banyak Berasal dari Indonesia. [online]. http://teknologi.metrotvnews.com/news-teknologi/gNQ6QWqb-peminat-iphonepaling-banyak-berasal-dari-indonesia [25 September 2018]

Anggraini, Ervina. (2017). Penjualan iPhone Terjun Bebas di Q2 2017. [online]. https $/ /$ www.cnnindonesia.com/teknologi/20170503100001-185-

211841/penjualan-iphone-terjun-bebas-di-q2-2017 [7 Oktober 2018]

Badan Pusat Statistik. (2013). Proyeksi Penduduk Indonesia 2010-2035. Jakarta: Badan Pusat Statistik.

Bambang, R. Lubis, dan Nurdasila, Darsono. (2017). Pengaruh Brand Image, Brand Personality, Brand Experience Terhadap Brand Love Dampaknya Pada Brand Loyalty Gayo Aceh Coffee PT. Oro Kopi Gayo Kabupaten Aceh Tengah. Vol 8, 163-164.

eMarketer. (2015). Proyeksi Pengguna Smartphone di Asia Tenggara 2016-2019. [online]. https://databoks.katadata.co.id/datapublish/2016/08/08/proyeksipengguna-smartphone-di-asia-tenggara-2016-2019 [15 September 2018]

Ghozali, imam dan Hengky Latan. (2015). Partial Least Squares Konsep, Teknik dan Aplikasi Menggunakan SmartPLS 3.0 untuk Penelitian Empiris (Edisi ke 2). Semarang : Universitas Diponegoro.

Hair Joseph F, G.Thomas, Christian M dan Marko Sarstedt. (2017). A Primer on Partial Least Squares Structural Equation Modeling (PLS-SEM).United States of America : Sage Publications, Inc.

Huang, Chin Chou. (2017). The Impact of Brand Loyalty: mediators of brand love and trust. Vol.55, 915-934.

IDC. (2018). IDC Indonesia: 2Q18 Smartphone Shipments Post New Record High with Xiaomi Disrupting the Market into a New Phase. [online]. https://www.idc.com/getdoc.jsp?containerId=prAP44263418 $\quad\left[\begin{array}{ll}17 & \text { September }\end{array}\right.$ 2018]

Latan, H., \& Noonan, R. (2017). Partial Least Squares Path Modeling: Basic Concepts, Methodological Issues and Applications. Springer International Publishing AG 2017.

Nyohardi, Paramita. (2016). Pengaruh Brand Experience Terhadap Brand Loyalty Melalui Brand Satisfaction Dan Brand Attitude, 52(11), 163. Retrieved from Jurnal Bisnis Dan Manajemen.

Rahmayani, Indah. (2015). Indonesia Raksasa Teknologi Digital Asia. [online]. https://kominfo.go.id/content/detail/6095/indonesia-raksasa-teknologi-digitalasia/0/sorotan_media [10 Oktober 2018]

Sari, Niken Permata dan Retno, Widowati. (2014). Hubungan Antara Kesadaran Merek, Kualitas Persepsian, Kepercayaan Merek dan Minat Beli Produk Hijau. Vol 5, 66. 
Schiffman, Leon G, Leslie, Lazar K dan Havard, Hansen. (2012). Consumer Behaviour A European Outlook (Edisi ke 2). England : Pearson Education Limited.

Sebayang, Rehia. (2018). Penjualan iPhone Lesu, Apple Kehilangan Rp 891 T dalam 3 Hari. [online]. https $/ /$ www.cnbcindonesia.com/market/20180425160220-1712462/penjualan-iphone-lesu-apple-kehilangan-rp-891-t-dalam-3-hari $[9$ Oktober 2018]

Sidabutar, Carlos Bryan dan Diah Dharmayanti. (2015). Analisa Pengaruh Brand Experience Terhadap Customer Loyalty Melalui Brand Trust, Customer Satisfaction Dan Customer Intimacy Sebagai Variabel Intervening Pada Kiehl's Surabaya. Vol. 1, 3.

Sudrajat, Darjat. (2015). Pengaruh Brand Image Dan Brand Identification Terhadap Brand Love Serta Dampaknya Pada Word Of Mouth Pelanggan Atas Restoran Bumbu Desa Cabang Cikini. Skripsi pada Binus University. 